\title{
Receptors for luteinizing hormone in different portions of the oviducts in estrus' mares
}

\author{
Jonas Flores 1,2, Ana Maria Telles Esmeraldino³, Rosangela Ferreira Rodrigues², Luis Augusto Cruz ${ }^{2}$, Rodrigo Costa Mattos ${ }^{1}$, Sandra \\ Mara Fiala Rechsteiner ${ }^{2}$ \\ 'PPGMAE - UFRGS, Porto Alegre (Brazil) \\ ${ }^{2}$ HISTOREP - Biology Institute, Morphology Department, UFPel - Pelotas (Brazil) \\ ${ }^{3}$ Veterinary Faculty ULBRA - Canoas (Brazil)
}

\begin{abstract}
Summary: Luteinizing hormone receptors (RLH) are expressed in gonadal cells and in several non-gonadal female and male tissues including the mare's oviduct. This study aimed to verify the presence RLH in different portions of the oviduct using the technique of immunohistochemistry. With these proposal 18 estrus mares that had a follicle greater than $35 \mathrm{~mm}$ and reproductive tract consistent with the estrogen phase of the estrous cycle were used. From the 18 mares that were part of the study, 16 mares (88.8\%) had receptors for luteinizing hormone (RLH) in the oviduct. A greater intensity of receptors was verified in the ampulla of the oviduct, which may be related to the LH in the process of fertilization of the oocyte by the sperm.
\end{abstract}

Keywords: Mare / oviduct / hormone receptors / immunohistochemistry / luteinizing hormone / reproduction

Correspondence: Dr. Sandra M. Fiala Rechsteiner, HISTOREP, Biology Institute, Morphology Department, UFPel-Pelotas (Brazil), E-mail: sandrafiala@yahoo.com.br

Citation: Flores J., Telles Esmeraldino A. M., Ferreira Rodrigues R., Cruz L. A., Mattos R. C., Fiala Rechsteiner S. M. (2014) Receptors for luteinizing hormone in different portions of the oviducts in estrus' mares. Pferdeheilkunde 30, 42-44

\section{Introduction}

The Luteinizing hormone receptors (RLH) have been demonstrated in several species including human, bovine, porcine, turkey and mouse uterine tubes (Fields and Shemesh 2004). The following tissues and cells are LH/hCG receptor positive in female. Oviduct, uterus, cervix, urinary bladder, oocyte/early embryo/blastocyst, placenta, fetal membranes, decidua, umbilical cord, brain, pineal gland, spinal cord, cavernous sinus carotid rete vascular complex, neural retina, pituitary gland, breast, skin, adrenal gland, blood vessels in target tissues, cells of immune system and bone (Rao and Ley 2007). The intensity of the immunocytochemical reaction in some species like the pig depends on the hormonal status of the animals (Zieck et al. 2005).

Esmeraldino et al. (2010) demonstrated the presence of $\mathrm{LH}$ receptors in the oviduct of mares, but without elucidate the functionality of the LHR in the mare's oviduct, and without showing if there is a variation in the presence of receptors for this hormone in different portions of the oviduct in these species.

The present study aimed to investigate the presence and intensity of hormone receptors for $\mathrm{LH}$ in different portions of the oviduct (isthmus, ampulla and infundibulum) of mares in estrus through the immunohistochemistry technique.

\section{Material and Methods}

Eighteen mares with unknown reproductive history belonging to an abattoir in southern Brazil were used in this trial. The mares were submitted to gynecological examination, which consisted of rectal palpation and ultrassonography and those that were in estrus, with follicles greater than $35 \mathrm{~mm}$ and reproductive tract consistent with the estrogenic phase of the estrous cycle were used. After slaughter, the reproductive tracts of these mares were collected. Three samples were collected from each oviduct, corresponding to the isthmus, ampulla and infundibulum. The samples were fixed in $4 \%$ buffered formalin, stained with hematoxylin-eosin and analyzed under a light microscope (400x). Immunohistochemistry was performed using the peroxidase anti-peroxidase technique. Rabbit polyclonal anti human-LH receptor (Santa Cruz Biothecnology, Inc.) served as primary antibodies to determine receptor status in epithelial, muscular and glandular structures. Control in which tissues sections stained with diluent without the primary antibody was negative.

The estrogen receptor Quickscore proposed by Detre et al. (1995) was used. The proportion of cells staining positively throughout the section was assigned from score 1 to $6(1=$ $0-4 \% ; \quad 2=5-19 \% ; \quad 3=20-39 \% ; \quad 4=40-59 \%$; $5=60-79 \% ; 6=80-100 \%)$. The whole section was scanned at low power in order to gauge the general level of intensity throughout the section, in the endothelium, mesothelium, epithelial cells and muscular layer. The average intensity, corresponding to the presence of negative (0), weak (1), intermediate (2) and strong (3) staining was evaluated and a multiplicative index (proportion of cells stained $x$ stain intensity) was calculated. Data were analyzed using ANOVA with statistical significance accepted at $P<0.05$. The calculated index was used as dependent variable. Statistical analysis of the experiment was conducted using statistix 9.0.

\section{Results}

From 18 mares used in this study, 16 mares $(88.8 \%)$ had receptors for luteinizing hormone (RLH) in the oviduct. All the- 
se mares showed reaction in the endothelium and mesothelium, but it wasn't possible to measure it. The percentage of mares showing RLH and the intensity of the receptors in the epithelium and muscle according to the uterine tube portion are shown in the tables 1 and 2 .

There was no significant difference $(P=0.4316)$ in the intensity of receptors in the isthmus of the oviduct related to the type of tissue studied (epithelium $x$ muscle) the same occurring in ampulla $(P=0.3463)$, however there was a difference in the infundibulum $(P=0.001)$, where the intensity of receptors on the epithelium was higher compared to the muscular layer. There was a greater intensity of receptors in the ampulla of the oviduct when analyzing the intensity of the receptors in the epithelium $(P=0.001)$ compared to the isthmus and infundibulum and the muscular layer of the ampulla $(P=0.0001)$ compared to the other portions.

\section{Discussion}

Luteinizing hormone receptors were observed in the fallopian tubes of different species (Fields and Shemesh 2004, Esmeraldino et al. 2010), however studies demonstrating the presence of receptors $\mathrm{LH}$ in different portions of the uterine tubes had not been performed in the equine, according to the literature reviewed. The presence of the LHR was observed in the vessels endothelium and mesothelium but it was not possible to quantify the intensity of these receptors. In human the most remarkable immunostaining was seen in the mucosa epithelium, and staining of the epithelium of the ampulla to LHR was more intense than in the epithelium of the isthmus. The same was observed in this study, with the ampulla showing a higher staining, regardless of the tissue studied. The myosalpinx staining was less intense than the mucosa (Lei et al. 1993), which agrees with the findings of this study with the exception of the mucosa of the infundibulum, where there was greater staining intensity, with only a mare presenting staining in the muscular infundibulum layer.

In rats, RLH were not detected in the mucosa of the oviduct, but were found in serous and sub-epithelial cells of the oviduct (Zheng et al. 2001). It has not been possible to verify whether these differences reflect differences between species or are the result of different experimental techniques. A hormonal profile dependent differential distribution of
$\mathrm{LH} / \mathrm{hCG}$ receptors in various oviductal cells, may imply the possibility of a direct involvement of $\mathrm{LH}$ in the regulation of the function of oviduct (Ziecik et al. 2007). LH and hCG can increase production of prostaglandins in endometrium, oviduct, and blood vessels. It is suggested that the preovulatory surge of $\mathrm{LH}$ plays an important role in controlling oviductal contractions (Ziecik et al. 2001). The presence of receptors for $\mathrm{LH} / \mathrm{hCG}$ in many cells of the oviduct and changes in the number of receptors depending on the hormonal status of the animal, suggests that LH may modulate spontaneous contractions of the oviduct in pigs, particularly during the preovulatory estrous cycle (Gawronska et al. 1999), same period used in this study, since mares were in estrus.

It seems that the preovulatory surge of $\mathrm{LH}$, beside its major action on the follicle rupture and luteinization of granulosa and theca cells, plays also an important role in the control of oviduct contraction. LH might also be a major factor responsible for opening the ampulla-isthmic junction for spermatozoa and synchronization of fertilization in the ampulla. Moreover, the known relaxing action of LH may facilitate the transport of embryos through the isthmus toward the uterus (Ziecik et al. 2007).

\section{Conclusion}

The intensity of RLH was higher in the epithelium of the infundibulum compared to the muscular layer. The intensity of receptors was higher in the ampulla of the uterine tube in both the epithelium and the muscular layer compared to the isthmus and infundibulum.

\section{References}

Detre S., Jotti S., Dowsett M. A. (1995) "quickscore" method for immunohistochemical semiquantitation: validation for oestrogen receptor in breast carcinomas. J. Clin. Pathol. 48, 876-878

Esmeraldino A. T., Malschitzky E., Fiala S.vM., Santarém L., Wolf C.vA., Jobim M. I. M., Gregory R. M., Mattos R. C. (2010) Imunohistochemical identification of luteinizing hormone receptors in the extra-gonadal reproductive tract of the mare. Anim. Reprod. Sci. 121, 38-39

Fields M., Shemesh M. (2004) Extragonodal luteinizing hormone receptors in the reproductive tract of domestic animal. Biol. Reprod. 71, 1412-1418

Table 1 - Intensity of LH receptors in the epithelium of the oviduct of mares in estrus. / LH-Rezeptorintensität im Eileiterepithel von östrischen Stuten

\begin{tabular}{lcccc}
\hline & Number of mares & \% of mares & Mean & SD $( \pm)$ \\
\hline Isthmus & 8 & 50 & 1.5 & 0.5345 \\
Ampulla & 14 & 87.5 & 2.5 & 0.6504 \\
Infundibulum & 10 & 62.5 & 2.6 & 0.6992 \\
\hline
\end{tabular}

Table 2 - Intensity of LH receptors in the muscular layer of the oviduct of mares in estrus. / LH-Rezeptorintensität in der Muskularis des Eileiters von östrischen Stuten

\begin{tabular}{lcccc}
\hline & Number of mares & \% of mares & Mean & SD $(\underline{\underline{\underline{ \pm}}})$ \\
\hline Isthmus & 6 & 37.5 & 1.33 & 0.5164 \\
Ampulla & 13 & 81.25 & 2.3 & 0.4804 \\
Infundibulum & 1 & 6.25 & 3 & 0 \\
\hline
\end{tabular}


Gawronska B., Paukku T., Huhtainiemi I., Wasovicz G., Ziecik A. J. (1999) Oestrogen-dependent expression of LH/hCG receptors in pig fallopian tube and their role in relaxation of the oviduct. J. Reprod. Fert. 115, 293-301

Lei Z. M., Toth O., Rao C. H. V., Pridham D. (1993) Novel coexpression of human chorioninc gonadotropin (hCG)/ human luteinizing hormone receptors and their ligand hCG in human fallopian tubes. Clin. Endocrinol. Metab. 863-872

Zheng M., Shi H., Segaloff D. L., van Morrhis B. J. (2001) Expression and localization of luteinizing hormone receptor in the female mouse reproductive tract. Biol. Reprod. 64, 179-187
Ziecik A. J., Derecka K., Gawronska B., Stepien A., Bodek G. (2001) Nongonadal $\mathrm{LH} / \mathrm{hCG}$ receptors in pig: functional importance and parallels to human. Semin. Reprod. Med. 19, 19-30

Ziecik A. J., Kaczmarek M. M., Blitek A., Kowalsky A., Li X., Rahman N. A. (2007) Novel biological and possible applicable roles of $\mathrm{LH} / \mathrm{hCH}$ receptor. Mol. Cell. Endocrinol. 269, 51-60

Ziecik A. J., Bodek G., Blitek A. (2005) Nongonodal LH receptors, their involvement in female reproductive function and a new applicable approach. Vet. J. 169, 75-84

\title{
Rezeptoren für Luteinisierendes Hormon in unterschiedlichen Abschnitten des Ovidukts bei Stuten im Östrus
}

LH-Rezeptoren werden in Keimzellen sowie in zahlreichen nicht gonadalen weiblichen und männlichen Geweben einschließlich des Stuteneileiters exprimiert. Ziel dieser Studie ist es, das Vorkommen von LH-Rezeptoren in verschiedenen Abschnitten des Eileiters mit Hilfe der Immunhistochemie zu überprüfen. Zu diesem Zweck wurden 18 östrische Stuten, die einen Follikel aufwiesen, der größer war als 35 mm, und deren Zustand des Genitaltraktes sich mit der Follikelphase in Einklang befand, zur Untersuchung herangezogen. Von den 18 Stuten hatten 16 Tiere (88,8\%) LH-Rezeptoren im Ovidukt. Eine größere Intensität der Rezeptoren wies die Ampulla des Eileiters auf, was auf einen Zusammenhang des LH mit dem Fertilisationsprozess der Eizelle durch die Spermien vermuten lässt.

Schlüsselwörter: Stute / Eileiter / Hormonrezeptoren / Immunhistochemie / Luteinisierendes Hormon / Reproduktion

8th ICERM Abstract

\section{CRISP-3 and lactoferrin in equine seminal plasma are involved in selective sperm transport in the mare's reproductive tract}

\author{
E. M. Woodward, M. H. T. Troedsson, A. L. Doty, A. Esteller-Vico, K. E. Scoggin \\ Maxwell H. Gluck Equine Research Center, Department of Veterinary Science, University of Kentucky, Lexington
}

Correspondence: Elizabeth Woodward; The Maxwell H. Gluck Equine Research Center, Department of Veterinary Science, University of Kentucky, Lexington, KY, 40546-0099, USA. E-mail: elizabeth.woodward@uky.edu

Semen induces a transient uterine inflammatory response in the mare, characterized by an influx of polymorphonuclear neutrophils (PMNs) to the uterine lumen. The physiological role of this inflammation is to clear excess and damaged spermatozoa, and bacterial contaminants from the uterus in order to provide an environment that is compatible with normal embryonic development and survival. PMNs are present in the uterine lumen within 0.5 hours after breeding, but sperm transport to the oviduct is not completed until 4 hours after breeding. Therefore, fertility would benefit if viable spermatozoa in the mare's reproductive tract were protected from being phagocytosed by PMNs while non-viable spermatozoa is targeted and eliminated. Based on previous studies, we hypothesized that specific proteins in equine seminal plasma are involved in selective sperm transport and elimination from the female reproductive tract. Specifically, we investigated if 1) CRISP-3 protects live spermatozoa from binding to PMNs, and 2) if lactoferrin promotes PMN-binding of dead spermatozoa.

Two separate experiments were conducted. Experiment 1: CRISP-3 was purified from equine seminal plasma by HPLC and the identity of the protein was confirmed with a western blot. Five stallions were collected three times each, and only ejaculates with $>60 \%$ progressively forward motility was used. Spermatozoa were washed and reconstituted in a commercial semen extender. Aliquots were stored at room temperature for $1 \mathrm{hr}$ (live $=\mathrm{LS}$ ), or snap frozen in liquid nitrogen for $1 \mathrm{hr}$ followed by thawing at room temperature (dead sperm $=$ DS). PMNs were isolated from peripheral blood from a healthy mare. Binding of sperm populations to PMNs in the presence pooled seminal plasma, CRISP-3, and Hanks buffered media was analyzed by flow cytometry. Experiment 2: Lactoferrin was purified from equine seminal plasma by HPLC and the identity of the protein was confirmed with a western blot. Semen was collected and pooled from four stallions, washed twice in LRS and freeze-killed in liquid nitrogen followed by thawing at room temperature. Blood derived PMNs were incubated for 30 minutes with spermatozoa stained with propidium iodide (PI). PMNs and spermatozoa were incubated in the presence of Hank's balanced salt solution, pooled seminal plasma, or lactoferrin (150 ug/mL). PMN-sperm binding was determined using flow cytometry. In addition, immunocytochemistry was used to determine binding of lactoferrin to LS and DS. Comparisons between treatments were analyzed using a one-way ANOVA and Bonferroni's comparison tests if normally distributed, and by Kruskal-Wallis ANOVA if not normally distributed. Significance was set at $p<0.05$. Incubation of LS with SP and CRISP-3 suppressed binding to PMNs $(23.06 \pm 3.98 \%$ and $2.06 \pm 2.02 \%$ respectively) when compared to incubation of LS in Hanks media (63.09 $\pm 8.67 \%$; $\mathrm{p}<0.0001)$. No effect was detected for CRISP-3 on binding of DS to PMNs when compared to incubation in Hanks media. In experiment 2 , both lactoferrin $(62.5 \pm 3.3 \%)$ and seminal plasma $(76.5 \pm 0.3 \%)$ treatments significantly enhanced binding of PMNs to DS as compared to control media (42.9 $\pm 1.6 \%)$. Lactoferrin treated DS showed a specific pattern of fluorescence on the acrosome region and the sperm tail. In contrast, LS did not show positive staining with lactoferrin. It was concluded that CRISP-3 and lactoferrin play important but different roles in sperm transport and elimination from the mare's reproductive tract after breeding. 